\title{
A non-canonical peptide synthetase adenylates 3-methyl-2-oxovaleric acid for auriculamide biosynthesis
}

\author{
Daniel Braga ${ }^{1,2}$, Dirk Hoffmeister ${ }^{1}$ and Markus Nett ${ }^{*}$
}

\section{Letter}

\section{Address:}

${ }^{1}$ Friedrich-Schiller-Universität Jena, Department Pharmaceutical Microbiology at the Hans-Knöll-Institute, Winzerlaer Strasse 2, 07745 Jena, Germany, ${ }^{2}$ Friedrich-Schiller-Universität Jena, Junior Research Group Synthetic Microbiology at the Hans-Knöll-Institute, Adolf-Reichwein-Strasse 23, 07745 Jena, Germany and ${ }^{3}$ Department of Biochemical and Chemical Engineering, Technical Biology,

Technical University Dortmund, Emil-Figge-Strasse 66, 44227 Dortmund, Germany

\section{Email:}

Markus Nett ${ }^{*}$ - markus.nett@bci.tu-dortmund.de

* Corresponding author

\section{Keywords:}

adenylation; auriculamide; biosynthesis; Herpetosiphon; nonribosomal peptide synthetase

\author{
Beilstein J. Org. Chem. 2016, 12, 2766-2770. \\ doi:10.3762/bjoc. 12.274 \\ Received: 02 September 2016 \\ Accepted: 07 December 2016 \\ Published: 16 December 2016 \\ This article is part of the Thematic Series "Chemical biology". \\ Guest Editor: H. B. Bode \\ (C) 2016 Braga et al.; licensee Beilstein-Institut. \\ License and terms: see end of document.
}

\begin{abstract}
Auriculamide is the first natural product known from the predatory bacterium Herpetosiphon aurantiacus. It is composed of three unusual building blocks, including the non-proteinogenic amino acid 3-chloro-L-tyrosine, the $\alpha$-hydroxy acid L-isoleucic acid, and a methylmalonyl-CoA-derived ethane unit. A candidate genetic locus for auriculamide biosynthesis was identified and encodes four enzymes. Among them, the non-canonical $199 \mathrm{kDa}$ four-domain nonribosomal peptide synthetase, AulA, is extraordinary in that it features two consecutive adenylation domains. Here, we describe the functional characterization of the recombinantly produced AulA. The observed activation of 3-methyl-2-oxovaleric acid by the enzyme supports the hypothesis that it participates in the biosynthesis of auriculamide. An artificially truncated version of AulA that lacks the first adenylation domain activated this substrate like the full-length enzyme which shows that the first adenylation domain is dispensable. Additionally, we provide evidence that the enzyme tolerates structural variation of the substrate. $\alpha$-Carbon substituents significantly affected the substrate turnover. While all tested aliphatic $\alpha$-keto acids were accepted by the enzyme and minor differences in chain size and branches did not interfere with the enzymatic activity, molecules with methylene $\alpha$-carbons led to low turnover. Such enzymatic plasticity is an important attribute to help in the perpetual search for novel molecules and to access a greater structural diversity by mutasynthesis.
\end{abstract}

\section{Findings}

Herpetosiphon aurantiacus is a filamentous, Gram-negative bacterium with a facultative saprophytic predatory behaviour $[1,2]$. For a more profound insight into the predation strategies

among bacteria, along with the underlying chemistry, the complete genome of $H$. aurantiacus $114-95^{\mathrm{T}}$ (ATCC 23779, DSM 785) was sequenced and analysed [3]. Present as one circular 
chromosome and two circular plasmids, the $6.8 \mathrm{Mb}$ genome of H. aurantiacus encodes as many as 14 biosynthesis gene clusters corresponding to $6.6 \%(0.45 \mathrm{Mb})$ of the genome. This capacity highlights this microorganism as a promising source of natural products. Genes for nonribosomal peptide synthetases (NRPSs) were found to be preponderant, either solely or organised in combination with polyketide synthase (PKS) genes, representing four and five clusters, respectively. Two PKS and three putative bacteriocin gene clusters complete the total set involved in the biosynthesis of natural products. Contrasting the high number of biosyntheses deduced from genomic data, knowledge on the actual natural products is limited. Recently, the dipeptide auriculamide (1, Figure 1), and the diterpene $O$-methylkolavelool were observed in cultures of $H$. aurantiacus $114-95^{\mathrm{T}}$, providing initial evidence for the assumed secondary metabolome of this species [4-6]. Within the entire genus, $\mathbf{1}$ is only the second PKS/NRPS-derived molecule to be described, following the report on siphonazole (2, Figure 1) [7]. Retrobiosynthetic analysis allowed the identification of a $14,130 \mathrm{bp}$-gene cluster, now referred to as aul-cluster (Figure 2), which putatively encodes two NRPSs (AulA and AulB) and one PKS (AulC) possessing domains that collectively allow and plausibly explains the assembly of $\mathbf{1}$. A gene for a type-II thioesterase is also found at the 3 ' portion of the aul cluster that may help unload misacylated carrier protein domains $[8,9]$.
Contrasting the standard layout of NRPSs, the amino acid sequence of one of the deduced NRPSs, termed AulA (1818 aa, $199 \mathrm{kDa}$ ), reveals the peculiar chimeric $\mathrm{A}_{1}-\mathrm{A}_{2}-\mathrm{KR}-\mathrm{PCP}$ architecture (Figure 2) [10]. Of particular interest, the occurrence of two sequential adenylation (A) domains is a very rare feature and only preceded by PyrG from Streptomyces pyridomyceticus [11].

Since the lack of a genetic system for $H$. aurantiacus makes the use of reverse genetics prohibitive, we sought to provide biochemical evidence for the participation of this unusual NRPS in the biosynthesis of 1. AulA is suggested to incorporate L-isoleucic acid (= 2-hydroxy-3-methylvaleric acid). The domain architecture indicates the substrate undergoes no other chemical modification besides a reductive step after being tethered to the PCP domain by the PKS-type ketoreductase domain $(\mathrm{KR})$, as reported for other natural products, such as pyridomycin [11], cereulide, valinomycin [12], and bacillaene [13]. Hence, the molecule to be recognized and activated by AulA would be 3-methyl-2-oxovaleric acid (3).

Seminal work with gramicidin synthetase from Bacillus brevis led to the identification of ten positions within an A domain (PheA), collectively referred to as nonribosomal code [14], that control substrate selectivity. Further research started to establish a relationship between this code and structural require-<smiles>CCC(=O)C(Cc1ccc(O)c(Cl)c1)NC(=O)C(C)O</smiles><smiles>C=C/C=C/CNC(=O)c1nc(CC(=O)c2nc(/C=C/c3ccc(OC)c(O)c3)oc2C)oc1C</smiles>

Figure 1: Herpetosiphon natural products auriculamide (1) and siphonazole (2).

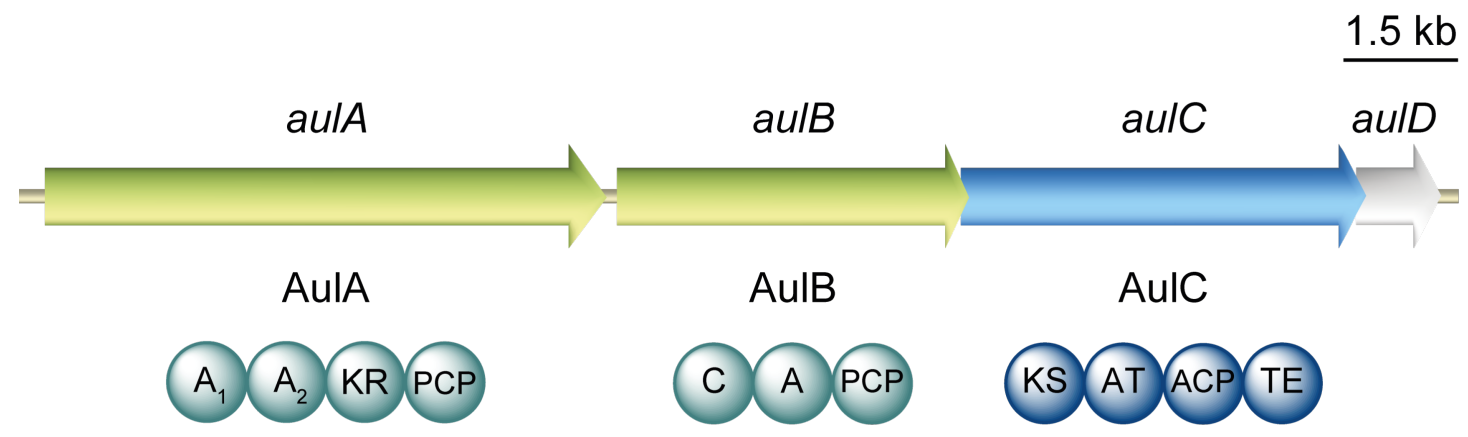

Figure 2: Organisation of the aul biosynthetic gene cluster. Circles illustrate the domain architecture of the NRPSs and the PKS present therein. Domains are abbreviated as A, adenylation; ACP, acyl carrier protein; AT, acyl transferase; $C$, condensation; KR, ketoreductase; KS, ketosynthase; PCP, peptidyl carrier protein; TE, thioesterase. The gene auID encodes a type II thioesterase. 
ments of the monomers to be recognised and incorporated to form the product $[15,16]$. In silico tools to identify the nonribosomal code, namely PKS/NRPS Analysis [17] and NRPSpredictor2 [18], are often accurate for the analysis of bacterial NRPSs. Yet, in our case, none retrieved any result after the

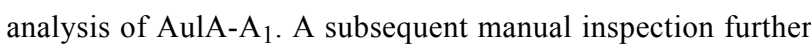
revealed that the acyl-activating consensus motif is hardly conserved in AulA- $\mathrm{A}_{1}$. Moreover, the strictly invariant residue Asp413, which is essential for adenylate binding [14] was replaced by a tyrosine residue in AulA- $\mathrm{A}_{1}$. We hence concluded that this domain cannot function as an adenylating enzyme and is likely skipped during the biosynthetic assembly. Inspection of AulA-A $\mathrm{A}_{2}$ with PKS/NRPS Analysis [17] and NRPSpredictor2 [18] yielded the nonribosomal code G-I-F-WL-G-A-S-G-- (Table 1). Although the last position was not detected, evidences support its occupancy by a remarkably conserved lysine residue (K517 in PheA) [19], whose side chain counters the negative charge of the substrate's carboxy group $[14,20]$. Also, the relationship between the expected substrate and the nonribosomal code of AulA-A 2 posed itself as a conundrum. The first position (D235 in PheA) is normally indicative of the substrate class to be used by the NRPS. Curiously, in AulA- $\mathrm{A}_{2}$ this corresponds to a glycine residue, associated with the activation of anthranilic acid [21,22] and diverts from what is often observed for the activation of aliphatic or aromatic $\alpha$-keto acids, where the nonribosomal code starts with a valine residue [23]. In the face of this preliminary analysis it remained elusive if and how AulA- $\mathrm{A}_{1}$ would contribute to the biosynthesis of auriculamide, e.g., through structural support for the catalytic role of AulA-A $\mathrm{A}_{2}$, as noticed with a fungal A domain [24]. In order to evaluate the individual biosynthetic contribution of each A domain, we assembled two constructs to express aulA both as full-length gene and as an artificial open reading frame solely encoding the AulA- $\mathrm{A}_{2}$ domain, the $\alpha$-keto reductase domain, and the terminal carrier protein. Independently, E. coli KRX was transformed with both constructs for heterologous production of the respective $N$-terminally hexahistidine fusion proteins, which were purified by metal affinity chromatography (Supporting Information File 1, Figure S1).

To probe their enzymatic activity, the two purified AulA fusion proteins were subjected to the ATP- $\left[{ }^{32} \mathrm{P}\right]$ pyrophosphate exchange assay. In this assay, the protein is incubated with a potential substrate, ATP and radioactive pyrophosphate. The reversible back exchange of $\left[{ }^{32} \mathrm{P}\right]$ pyrophosphate into ATP is quantified by scintillation counting after solid phase capture of ATP on activated charcoal [25]. Both recombinant AulA variants tested against the assumed substrate 3 led to similar turnover (Figure $3 \mathrm{a}$ ) which demonstrates that the $\mathrm{A}_{1}$ domain is not essential for adenylation of $\mathbf{3}$ and PCP loading. Further functional characterization was carried out using the native four-domain enzyme $A_{1}-A_{2}-K R-P C P$. Maximum turnover of 3 was observed at $\mathrm{pH} 7.0$ and $30^{\circ} \mathrm{C}$. For more insight into the structural requirements of substrates, we assayed AulA against different molecules similar to $\mathbf{3}$, varying the functional group at the $\alpha$-carbon, position and number of methyl substituents, and chain length (Figure 3b, compounds 4-10). As anticipated, the presence of an $\alpha$-carbonyl notably influenced a successful adenylation. In the case of the tested $\alpha$-keto acids, the differences in the chain size or position of the methyl group did not seem to play a role, as demonstrated by the equal enzymatic preference for 3 (261,000 cpm), 4 (249,000 cpm) and 5 $(275,000 \mathrm{cpm})$. Conversely, the activation of $\alpha$-hydroxy acids was not uniform. 2-Hydroxy-4-methylvaleric acid (6) could also be recognized by the NRPS, albeit a slightly lower radiolabel exchange $(210,000 \mathrm{cpm})$ followed its incubation with the enzyme. Interestingly, the assay of 2-hydroxy-3-methylbutyric acid (7) resulted in a major decrease in the radiolabel exchange $(60,000 \mathrm{cpm})$ when compared to its $\alpha$-keto acid analogue. Molecules possessing a methylene $\alpha$-carbon were not suitable substrates for AulA. 4-Methylpent-2-enoic acid (8) was only modestly activated $(89,000 \mathrm{cpm})$, while reactions with 9 $(24,000 \mathrm{cpm})$ and $\mathbf{1 0}(28,000 \mathrm{cpm})$ resulted in negligible substrate turnover.

Our biochemical in vitro results highlight AulA as apt to take part on a NRPS/PKS complex for the biosynthesis of auriculamide, given the activation of 3-methyl-2-oxovaleric acid by its second adenylation domain. Our results also contribute to hone algorithms used to predict substrates from nonribosomal codes. Moreover, we describe how this enzyme is pliant to minor structural variations of that molecule, enabling future attempts to generate auriculamide analogues as potential new drug candidates.

\begin{tabular}{|c|c|c|c|c|c|c|c|c|c|c|c|c|}
\hline CesA-A 1 & ABD14711 & V & G & M & W & $\mathrm{N}$ & G & $\mathrm{T}$ & $S$ & I & $\mathrm{K}$ & 4-methyl-2-oxovaleric acid \\
\hline CesB- $A_{1}$ & ABD14712 & V & G & M & W & $\mathrm{N}$ & G & $\mathrm{V}$ & $S$ & V & $\mathrm{K}$ & 2-oxovaleric acid \\
\hline
\end{tabular}


a)

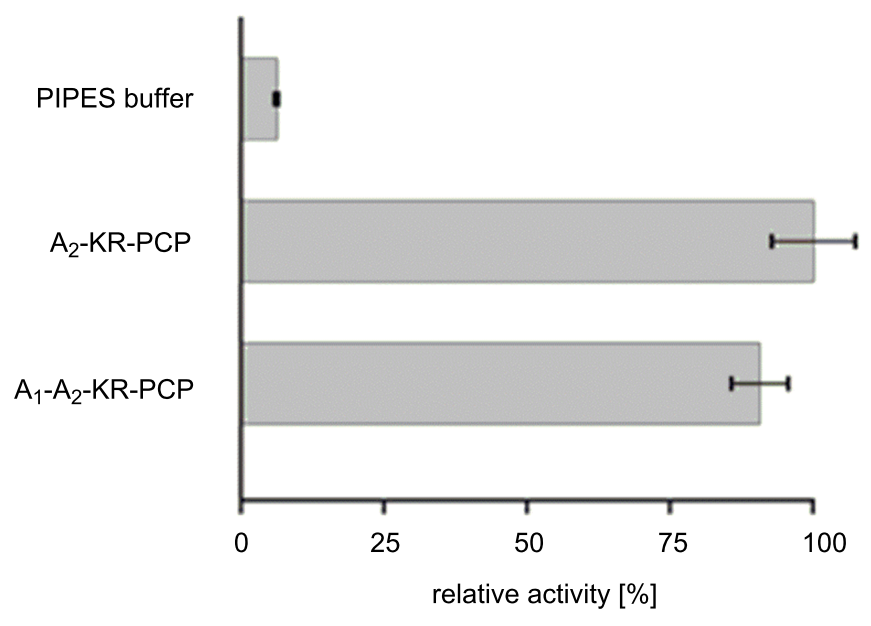

b)

3<smiles>CCC(C)C(=O)C(=O)O</smiles>

4<smiles>CC(C)CC(=O)C(=O)O</smiles>

5<smiles>CC(C)C(=O)C(=O)O</smiles>

6<smiles>CC(C)CC(O)C(=O)O</smiles>

7<smiles>CC(C)C(O)C(=O)O</smiles>

8<smiles>CC(C)/C=C/C(=O)O</smiles>

9<smiles>CCCCC(=O)O</smiles>

PIPES buffer

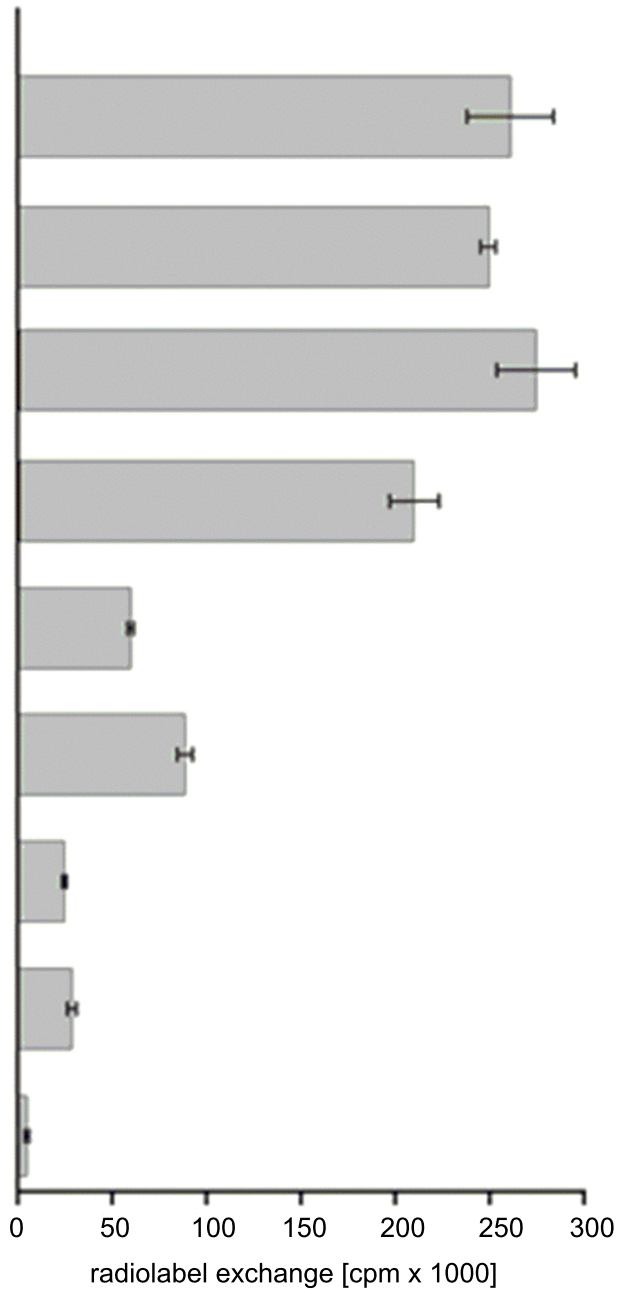

Figure 3: Testing of AulA ( $\left.A_{1}-A_{2}-K R-P C P\right)$ and a truncated variant $\left(A_{2}-K R-P C P\right)$ in the ATP-[32P]pyrophosphate exchange assay using 3-methyl-2oxovaleric acid as a substrate. Relative activities are referenced to the $A_{2}-K R-P C P$ enzyme (a). Substrate specificity of recombinant AulA in the ATP[ ${ }^{32}$ P]pyrophosphate exchange assay (b). All bar diagrams depict the substrate-dependent exchange based on the arithmetic mean of triplicate reactions. Error bars represent the standard deviations. Substrates with chiral centres were tested as racemic mixtures. PIPES buffer was used as negative control. 


\section{Supporting Information}

\section{Supporting Information File 1}

Complete experimental details.

[http://www.beilstein-journals.org/bjoc/content/

supplementary/1860-5397-12-274-S1.pdf]

\section{Acknowledgements}

D.B. gratefully acknowledges a doctoral fellowship from the International Leibniz Research School (ILRS Mibintact). We thank Wiebke Hanke and Dr. Hirokazu Kage for a preliminary analysis of AulA.

\section{References}

1. Holt, J.; Lewin, R. J. Bacteriol. 1968, 95, 2407-2408.

2. Jurkevitch, E. Microbe 2007, 2, 67-73. doi:10.1128/microbe.2.67.1

3. Kiss, H.; Nett, M.; Domin, N.; Martin, K.; Maresca, J. A.; Copeland, A.; Lapidus, A.; Lucas, S.; Berry, K. W.; Glavina Del Rio, T.; Dalin, E.;

Tice, H.; Pitluck, S.; Richardson, P.; Bruce, D.; Goodwin, L.; Han, C.; Detter, J. C.; Schmutz, J.; Brettin, T.; Land, M.; Hauser, L.; Kyrpides, N. C.; Ivanova, N.; Göker, M.; Woyke, T.; Klenk, H. P.; Bryant, D. A. Stand. Genomic Sci. 2011, 5, 356-370. doi:10.4056/sigs. 2194987

4. Schieferdecker, S.; Domin, N.; Hoffmeier, C.; Bryant, D. A.; Roth, M.; Nett, M. Eur. J. Org. Chem. 2015, 3057-3062. doi:10.1002/ejoc.201500181

5. Nakano, C.; Oshima, M.; Kurashima, N.; Hoshino, T. ChemBioChem 2015, 16, 772-781. doi:10.1002/cbic.201402652

6. Korp, J.; Vela Gurovic, M. S.; Nett, M. Beilstein J. Org. Chem. 2016, 12, 594-607. doi:10.3762/bjoc. 12.58

7. Nett, M.; Erol, Ö.; Kehraus, S.; Köck, M.; Krick, A.; Eguereva, E.; Neu, E.; König, G. M. Angew. Chem., Int. Ed. 2006, 45, 3863-3867. doi:10.1002/anie.200504525

8. Schwarzer, D.; Mootz, H. D.; Linne, U.; Marahiel, M. A. Proc. Natl. Acad. Sci. U. S. A. 2002, 99, 14083-14088. doi:10.1073/pnas.212382199

9. Pfeifer, B.; Hu, Z.; Licari, P.; Khosla, C. Appl. Environ. Microbiol. 2002, 68, 3287-3292. doi:10.1128/AEM.68.7.3287-3292.2002

10. Marchler-Bauer, A.; Derbyshire, M. K.; Gonzales, N. R.; Lu, S.; Chitsaz, F.; Geer, L. Y.; Geer, R. C.; He, J.; Gwadz, M.; Hurwitz, D. I.; Lanczycki, C. J.; Lu, F.; Marchler, G. H.; Song, J. S.; Thanki, N.; Wang, Z.; Yamashita, R. A.; Zhang, D.; Zheng, C.; Bryant, S. H. Nucleic Acids Res. 2014, 43 (Suppl. D1), D222-D226. doi:10.1093/nar/gku1221

11. Huang, T.; Li, L.; Brock, N. L.; Deng, Z.; Lin, S. ChemBioChem 2016, 17, 1421-1425. doi:10.1002/cbic.201600156

12. Magarvey, N. A.; Ehling-Schulz, M.; Walsh, C. T. J. Am. Chem. Soc. 2006, 128, 10698-10699. doi:10.1021/ja0640187

13. Calderone, C. T.; Bumpus, S. B.; Kelleher, N. L.; Walsh, C. T.; Magarvey, N. A. Proc. Natl. Acad. Sci. U. S. A. 2008, 105, 12809-12814. doi:10.1073/pnas.0806305105

14. Conti, E.; Stachelhaus, T.; Marahiel, M. A.; Brick, P. EMBO J. 1997, 16 4174-4183. doi:10.1093/emboj/16.14.4174

15. Stachelhaus, T.; Mootz, H. D.; Marahiel, M. A. Cell Chem. Biol. 1999, 6, 493-505. doi:10.1016/S1074-5521(99)80082-9
16. Challis, G. L.; Ravel, J.; Townsend, C. A. Cell Chem. Biol. 2000, 7, 211-224. doi:10.1016/S1074-5521(00)00091-0

17. Bachmann, B. O.; Ravel, J. Methods Enzymol. 2009, 458, 181-217. doi:10.1016/S0076-6879(09)04808-3

18. Röttig, M.; Medema, M. H.; Blin, K.; Weber, T.; Rausch, C.; Kohlbacher, O. Nucleic Acids Res. 2011, 39 (Suppl. 2), W362-W367. doi:10.1093/nar/gkr323

19. Kalb, D.; Lackner, G.; Hoffmeister, D. Fungal Biol. Rev. 2013, 27 , 43-50. doi:10.1016/j.fbr.2013.05.002

20. Schwarzer, D.; Finking, R.; Marahiel, M. A. Nat. Prod. Rep. 2003, 20, 275-287. doi:10.1039/b111145k

21. Ames, B. D.; Walsh, C. T. Biochemistry 2010, 49, 3351-3365. doi:10.1021/bi100198y

22. Gao, X.; Chooi, Y.-H.; Ames, B. D.; Wang, P.; Walsh, C. T.; Tang, Y. J. Am. Chem. Soc. 2011, 133, 2729-2741. doi:10.1021/ja1101085

23. Wackler, B.; Lackner, G.; Chooi, Y. H.; Hoffmeister, D. ChemBioChem 2012, 13, 1798-1804. doi:10.1002/cbic.201200187

24. Kalb, D.; Lackner, G.; Rappe, M.; Hoffmeister, D. ChemBioChem 2015, 16, 1426-1430. doi:10.1002/cbic.201500190

25. Linne, U.; Marahiel, M. A. Methods Enzymol. 2004, 388, 293-315. doi:10.1016/S0076-6879(04)88024-8

\section{License and Terms}

This is an Open Access article under the terms of the Creative Commons Attribution License (http://creativecommons.org/licenses/by/4.0), which permits unrestricted use, distribution, and reproduction in any medium, provided the original work is properly cited.

The license is subject to the Beilstein Journal of Organic Chemistry terms and conditions:

(http://www.beilstein-journals.org/bjoc)

The definitive version of this article is the electronic one which can be found at: doi:10.3762/bjoc. 12.274 